\title{
Komunikasi Interpersonal Komunitas Online www.rumahtaaruf.com
}

\author{
Nadya Zsalsabilla Rahmania, Indra N.A Pamungkas
}

Prodi S1 Ilmu Komuikasi, Fakultas Komunikasi dan Bisnis, Universitas Telkom, Bandung

\begin{abstract}
ABSTRAK
Menjalin hubungan merupakan sebuah kebutuhan yang harus dipenuhi oleh setiap manusia. Dengan adanya hubungan yang baik maka akan tercipta komunikasi yang efektif dibandingkan dengan komunikasi yang kurang baik. Salah satu cara menjalin hubungan adalah menjalin hubungan sosial dimana didalamnya terdapat hubungan kelompok. Dengan adanya perkembangan teknologi, menjalin hubungan atau komunikasi dengan kelompok atau organisasi bukan hanya dapat dilakukan secara langsung tetapi melalui media online. Komunitas online www.rumahtaaruf.com mencoba untuk memfasilitasi anggota kelompoknya untuk dapat berkomunikasi dan mencari pasangan melalui adanya taaruf online. Melalui komunitas online tersebut, komunikasi antar anggota yang ingin mencari pasangan dapat terjalin terutama dengan adanya media online yang sedang marak digunakan pada saat ini.

Penelitian ini dilakukan untuk mengetahui bagaimana komunikasi interpersonal yang terdapat pada pasangan yang merupakan anggota dari komunitas online www.rumahtaaruf.com. Metode yang digunakan dalam penelitian ini adalah metode kualitatif. Pengumpulan data dilakukan melalui observasi dan wawancara mendalam. Paradigma yang digunakan dalam penelitian ini yaitu paradigma postpositivis. Teknik analisis data yang digunakan adalah melalui teknik analisis data model Miles dan Huberman. Hasil penelitian menunjukan bahwa komunikasi interpersonal terjadi pada saat pertemuan tahap offline dan komunikasi dilakukan intens oleh ketiga informan setelah adanya pertemuan keluarga dan setelah adanya proses khitbah atau lamaran.
\end{abstract}

Kata-kata Kunci: Komunikasi Interpersonal, Komunitas Online, Online Dating

\section{Interpersonal Communication in Online Community www.rumahtaaruf.com}

\section{ABSTRACT}

Building relationships is a requirement that must be met by every human being. With the good relationship it will create effective communication compared to poor communication. One way is to establish a relationship in social relations are group relations. With the development of technology, in a relationship or communication with other groups or organizations do not only directly but also through online media. Www.rumahtaaruf.com online community try to facilitate the group members to be able to communicate and find a mate through their online ta'aruf. Through the online community, communication between members who want to find a partner can be established, especially with the emerging online media in use today.

This study was conducted to determine how the interpersonal communication contained in couples who are members of the online community www.rumahtaaruf.com. The method used in this research is qualitative method. Data collected through observation and interview. The paradigm used in this research is paradigm postpositivis. Data analysis technique used is the technique of data analysis model of Miles and Huberman.

The results showed that interpersonal communication occurs during the offline stage meetings and intense communication is performed by a third informant after their family gatherings and after their khitbah process or or after the engagement occurs.

Keywords: Interpersonal Communication, Community Online, Online Dating

Korespondensi: Nadya Zsalsabilla Rahmania. Telkom University. Jl. Telekomunikasi, Jl. Terusan Buah Batu No.01, Dayeuhkolot, Bandung, Jawa Barat 40257.Email: nadyazsalsabilla@ gmail.com

ISSN: 2548-3242 (cetak), eISSN: 2549-0079 Website: http://jurnal.unpad.ac.id/manajemen-komunikasi 


\section{PENDAHULUAN}

Keberadaan komunitas online sudah menjadi bagian dari perkembangan media saat ini. Perkembangan komunitaskomunitas yang pada awalnya hanya terbentuk pada realitas nyata kini berkembang dengan pesat sehingga memunculkan bentuk baru dari komunitas yang sebelumnya hanya terbentuk dari adanya komunikasi atau interaksi dalam dunia nyata. Dengan adanya perkembangan teknologi yang memungkinkan adanya kemudahan dalam melakukan interaksi antar individu sehingga hubungan antar manusia dapat terjalin dengan cepat tanpa batasan waktu. Membina hubungan merupakan salah satu kebutuhan yang diperlukan oleh setiap manusia. Membina hubungan merupakan sebuah sarana bagi manusia untuk dapat mejalin relasi dan berinteraksi dengan orang lain. Dengan adanya hubungan yang baik maka interaksi yang terjadi antar manusia juga akan menjadi lebih efektif dibandingkan dengan hubungan yang kurang baik. Namun dengan adanya komunitas online yang terbentuk, komunikasi anggota komunitas didalamnya belum sepenuhnya memberikan ruang untuk berinteraksi secara langsung bagi para anggota komunitas online tersebut.

Didalam Hirarki Kebutuhan yang dikemukakan oleh Maslow, terdapat salah satu kebutuhan mengenai kebutuhan sosial yaitu kebutuhan akan adanya interaksi dengan orang lain atau hubungan sosial. Sehingga membina hubungan merupakan suatu kebutuhan yang penting dimiliki dan harus dipenuhi dalam kehidupan manusia. Membina hubungan sosial dapat digolongkan menjadi berbagai macam jenis, salah satu diantaranya terdapat hubungan antar manusia dan hubungan antar kelompok. Salah satu bentuk dari perkembangan teknologi dan komunikasi memunculkan hubungan antar kelompok yang lebih luas dan tidak terbatas pada tempat sehingga memunculkan adanya global village yang menyatukan para pengguna ruang siber menjadi satu dengan adanya penggunaan media online.

Penggunaan situs online juga menjadi suatu trend yang berkembang pesat terutama di Indonesia. Pengguna situs online di Indonesia menurut Kementrian Komunikasi dan Informatika Republik Indonesia berdasarkan hasil riset dari lembaga riset pasar e-Marketer mencapai mencapai 83,7 juta pengguna pada tahun 2014 dan menjadikan Indonesia sebagai salah satu dari 5 Negara yang termasuk kedalam Negara dengan pengguna internet terbanyak didunia. Dari banyaknya pengguna ruang siber yang tersebut, komunitas online terbentuk dari adanya kesamaan tujuan antar anggota kelompoknya.

$$
\text { William C. Schultz }
$$
sebagaimana dikutip oleh Robbins dan Judge (2008) merumuskan teori Fundamental 
Interpersonal Relations Orientations (FIRO). Menurutnya orang menjadi anggota kelompok didorong oleh adanya kebutuhan interpersonal meliputi masuk menjadi anggota kelompok (Inclusion), mengendalikan orang lain dalam tatanan hierarksi (control) dan memperoleh keakraban emosional dengan anggota kelompok yang lain sehingga komunikasi interpersonal dalam suatu komunitas atau kelompok juga sangatlah penting. Salah satu komunitas online di Indonesia yang memfasilitasi para anggotanya untuk bertemu dalam satu ruang yang sama sesuai dengan ketertarikan dan kesamaan tujuannya adalah komunitas online www.rumahtaaruf.com, yang memungkikan pengguna atau anggotanya dapat berinteraksi satu sama lain untuk menemukan pasangan yang memiliki kecocokan dengan kepribadian angotanya. Rumah taauf merupakan komunitas online yang memfokuskan para anggotaya untuk mecari pasangan dan menjalani taaruf yang sebelumnya hanya dapat dilakukan secara langsung menjadi termudahkan dengan bantuan jaringan online.

Situs yang berdiri sejak 2001 ini memfasilitasi kaum muslim untuk menemukan jodohnya melalui ta'aruf online hingga ke jenjang pernikahan. Untuk bisa masuk dan mengakses program taaruf, pengunjung rumahtaaruf.com harus mengirimkan biodata yang disertai foto ke alamat yang tertera dalam situs tersebut sebagai syarat untuk menjadi anggota komunitas rumah taaruf. Dalam mejalani interaksi dengan calon pasangan yang juga merupakan anggota rumah taaruf yang memiliki kecocokan dengan salah satu anggota lainnya, ada beberapa tahapan komunikasi yang harus dijalani dan dipatuhi oleh para anggota komunitas online tersebut diantaranya terbagi menjadi tiga tahap yaitu tahap online, tahap mediasi dan tahap offline.

Berdasarkan latar belakang diatas, penulis tertarik untuk memilih rumusan masalah yang akan diteliti lebih mendalam pada penelitian ini yaitu mengenai bagaimanakah proses komunikasi interpersonal pasangan yang terbentuk dari anggota www.rumahtaaruf.com?

\section{Komunikasi Interpersonal}

Komunikasi merupakan proses penyampaian informasi yang menghasilan makna. Suryanto (2015) dalam bukunya mengutip bahwa Berelson dan Steiner (1964) menjelaskan pengertian komunikasi adalah proses penyampaian informasi, gagasan, emosi, keahlian, dan lain-lain melalui penggunaan simbol-simbol, seperti kata-kata, gambar, angka, dan lain-lain. Sedangkan menurut Ruben dan Steart (1998) definisi komunikasi meliputi semua respon terhadap pesan yang diterima lalu menciptakan pesan baru karena setiap orang berinteraksi dengan orang lain melal proses penciptaan dan 
interpretasi pesan yang dikemas dalam bentuk simbol atau kumpulan simbol bermakna yang sangat berguna (Suryanto, 2015: 50-51).

\section{Collin Cherry mendefinisikan} komunikasi sebagai usaha untuk membuat satuan sosial dari individu dengan menggunakan bahasa atau tanda. Dalam berkomunikasi pertukaran pesan-pesan yang disampaikan tersebut merupakan pesanpesan verbal yang tercermin melalui katakata atau ungkapan, juga pesan-pesan nonverbal seperti tanda, lambang atau simbol (Rakhmat, 2001: 5 dalam Novianti, 2014).

Komunikasi meliputi proses encoding pesan yang akan dikirimkan, dan proses decoding terhadap pesan yang akan diterima, serta melakukan sintesis terhadap informasi dan makna. Komunikasi dapat terjadi pada semua level pengalaman manusia dan merupakan cara terbaik untuk memahami perilaku manusia dalam perubahan perilaku antara individu, komunitas, organisasi, dan pendapat umumnya. Oleh karena itu, komunikasi dapat dipelajari secara empiris dan kritis pada berbagai derajat interaksi. Level-level ini dapat digambarkan pada tataran (Suryanto, 2015: 53):

1. Micro to micro, yaitu level komunikasi intrapersonal (cara individu memproses informasi);

2. Interpersonal (cara dua individu berinteraksi mempengaruhi satu sama lain);
3. Kelompok (cara dinamika komunikasi terjadi di antara banyak individu);

4. Organisasi formal dan informal (cara komunikasi terjadi dan berfungsi dalam konteks organisasi, komunitas, dan masyarakat atau cara komunikasi membangun atau mengubah agenda penting dari isu tertentu).

Laswell dalam Suryanto (2015: 54) secara eksplit dan kronologis menjelaskan lima komponen yang terlibat dalam komunikasi, yaitu siapa (pelaku komunikasi pertama yang mempunyai inisiatif sebagai sumber), mengatakan apa (isi informasi yang disampaikan) kepada siapa (pelaku komunikasi lainnya yang dijadikan sasaran penerma), melalui saluran apa (alat/saluran penyampaian informasi), dan dengan akibat apa (hasil yang terjadi pada diri penerima). Ini menjukan bahwa komunikasi adalah suatu upaya yang disengaja serta mempunyai tujuan

Proses komunikasi merupakan proses peleburan makna dari lambang-lambang komunikasi yang disampaikan komunikator dengan komunikan. Proses komunikasi melibatkan banyak faktor atau unsur yang ada didalamnya, yaitu pelaku atau peserta, pesan (meliputi bentuk, isi, dan cara penyajiannya), saluran, media atau alat yang dipergunakan untuk menyampaikan pesan, waktu, tempat, hasil atau akibat yang terjadi, hambatan yang muncul, serta situasi atau 
kondisi saat berlangsungnya proses komunikasi (Suryanto, 2015: 203).

Model komunikasi dalam proses komunikasi yang dikemukakan Shannon dan Weaver mengandaikan sebuah sumber daya informasi (source information) yang mencptakan sebuah pesan (message) dan mengirimnya dengan suatu saluran (Channel) kepada penerima (Receiver) kemudian membuat ulang (recreate) pesan tersebut.

antara orang-orang yang berkomuikasi dapat terjalin (Suryanto, 2015:110).

Komunikasi interpersonal menurut Mulyana (2000: 73) sebagaimana dikutip oleh Suryanto (2014) diartikan sebagai komunikasi antara orang-orang secara tatapmuka, yang memungkinkan setiap pesertanya menangkap reaksi orang lain secara langsung, baik secara verbal maupun non-verbal. Ia menjelaskan bentuk khusus dari komunikasi antarpribadi adalah komunikasi

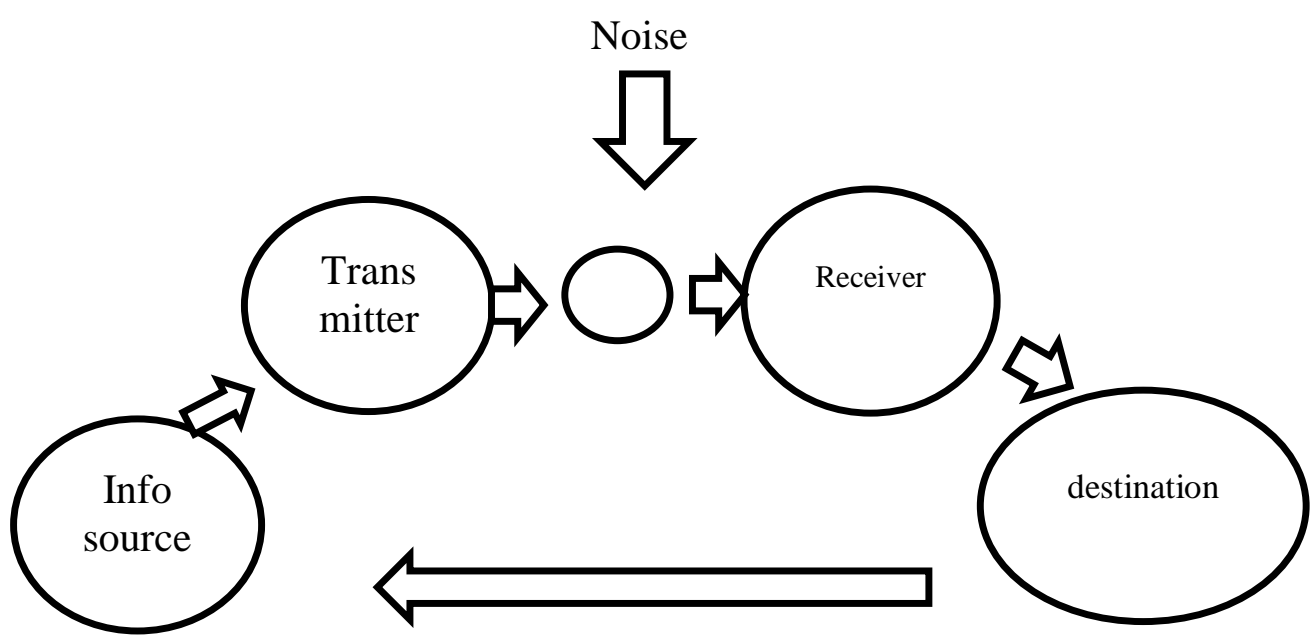
diadik yang hanya melibatkan dua orang...komun ikasi demikian menunjukan pihak-pihak yang

Gambar 1. Model Shannon dan Weaver Sumber: Suryanto,2015

Komunikasi interpersonal merupakan proses penyampaian pesan dari seseorang kepada orang lain (pihak lain). Menurut pengertian tersebut, komunikasi dikaitkan dengan pertukaran informasi yang bermakna dan harus membawa hasil diantara orangorang yang berkomunikasi. Komunikasi interpersonal menghendaki informasi atau pesan dapat tersampaikan dan hubungan berkomunikasi berada dalam jarak yang dekat, saling mengirim dan menerima pesan, baik verbal maupun nonverbal secara simultan dan spontan.

Kemampuan berkomunikasi secara efektif adalah kompetensi pengetahuan tentang konteks (interaksi, orang), pengetahuan tentang "rules" dari perilaku nonverbal. Penyebab $90 \%$ orang gagal dalam kehidupan adalah kegagalan dalam membina hubungan yang baik dengan orang lain (Suryanto, 2015: 110-111). 
Keterampilan seseorang ini melekat pada setiap pribadi dalam persentuhannya dengan masyarakat (baik individu maupun kelompok), yang dalam perwujudannya akan menampilkan sikap, tingkah laku, dan perbuatan yang mencerminkan keakuratan dalam menunjang pelaksanaan tugas.

Keterampilan dasar seseorang ini menurut Suryanto (2015), meliputi:

1. Keterampilan mengamati (observing skill);

2. Keterampilan menggambarkan (describing skill);

3. Keterampilan mendengarkan (listening skill);

4. Keterampilan bertanya (questioning skill);

5. Keterampilan meringkas (summarizing skill);

6. Keterampilan memberi dan menerima umpan balik (feedback skill).

\section{Konteks Komunikasi Interpersonal}

Suryanto (2015) dalam bukunya menjelaskan beberapa konteks komunikasi interpersonal meliputi:
A. Mendasarkan pada komponen komunikasi

Komunikasi interpersonal dipahami dengan mengamati komponen-komponen utamanya. Komponen-komponen itu diidentifikasi dari dan dalam proses penyampaian dan penerimaan pesan dari seseorang kepada orang lain atau sekelompok kecil orang dengan berbagai dampakan peluang untuk memberikan umpan balik segera. DeVito (dalam Maulana, 1997: 26) mengemukakan komponen-komponen itu dapat ditelusuri dari bagan komunikasi antarmanusia secara universal.

B. Konteks (Lingkungan)

Komponen komunikasi yang terlibat sebagai potensi terjadinya pesan yang akan disampaikan (saluran umpan balik), yaitu:
1) Sumber;
2) Enkoder;

3) Penerima;

4) Decoder;

5) Umpan balik;

6) Pesan yang akan disampaikan;

7) Gangguan distorsi;

8) Efek.

\section{Tujuan Komunikasi Interpersonal}

Tujuan komunikasi interpersonal sebagaimana dikemukakan DeVito (1992: 13-14) dalam Suryanto (2015: 120-121) adalah sebagai berikut:

1. Mempelajari secara lebih baik dunia luar, seperti berbagai objek, peristiwa, dan orang lain. Meskipun informasi tentang dunia luar dikenalkan melalui media massa, hal itu sering didiskusikan, dipelajari, diinternalisasi melalui komunikasi interpersonal...selanjutnya melalui komunikasi interpersonal, dapat mengevaluasi keadaan untuk dibandingkan dengan kondisi sosial 
orang lain. Cara ini menghasilkan selfconcept yang semakin berkembang dan mendorong perluasan pengetahuan dan keterampilan yang pada akhirnya melakukan perubahan/inovasi.

2. Memelihara hubungan mengembangkan kedekatan atau keakraban. Melalui komunikasi interpersonal, adanya keinginan menjalin rasa cinta dan kasih sayang. Disamping mengurangi rasa kesepian atau rasa depresi, komunikasi interpersonal bertujuan membagi dan meningkatkan rasa bahagia yang pada akhirnya mengembangkan perasaan positif tentang diri sendiri.

3. Mempengaruhi sikap-sikap dan perilaku orang lain. Dalam kehidupan masyarakat, kita sering mengajak dan membujuk seseorang untuk menetapkan cara-cara tertentu yang lebih menguntungkan...upaya untuk mempengaruhi pihak lain menjadi demikian penting bagi pengawas/penilik kependidikan yang tugasnya melakukan pembinaan.

4. Menghibur diri atau bermain. Tujuan menghibur diri atau bermain menjadi penting ketika orang sudah demikian serius dan beranjak stress dalam melaksanakan pekerjaan.

\section{Komunikasi dalam Media Siber (Online Comunication)}

Istilah mediamorfosis pertama kali diperkenalkan Roger Fidler dalam bukunya Mediamorfosis: Memahami Media Baru (2003). Ia ,mendefinisikan mediamorfosis sbagai transformasi media dari satu bentuk ke bentuk lainnya, sebagai akibat dari kombinasi perubahan budaya dan kedatangan teknologi baru. Mediamorfosis mendorong untuk memahami semua bentuk sebagai bagian dari sebuah system yang saling berkaitan dan mencatat berbagai kesmaan dan hubungan yang ada antara bentuk yang muncul pada masa lalu, masa sekarang dan masa yang sedang dalam proses kemunculannya. Media baru tidak akan muncul begitu lama. Ketika bentuk media komunikasi yang baru muncul, bentuk yang terdahulu tidak mati, tetapi berkembang dan beradaptasi (Fidler, 2003) dalam Suryanto (2015: 605).

Terry Flew (2005) dalam Suryanto (2015) mendefinisikan media baru sebagai kombinasi dari formar 3Cs, yaitu computing and information technology, communication networks, dan digitize media and iformation content. Media baru konsisten dengan pembelajaran teknologi media yang merujuk pada kebutuhan untuk menyadari cara mediasi dalam komunikasi melalui format teknologi yang telah menubah komunikasi dalam paktik sosial. Sementara Lievrouw dan Livingstone (2002) mengobservasi 
beberapa cara berpikir tentang media baru yang perlu untk dimasukan dalam tiga elemen, yaitu alat yang memperluas kemampuan untuk berkomunikasi, kegiatan komunikasi dan praktiknya dikaitkan dalam perkembangan dan penggunaan alat tersebut, arahan sosial dan organisasi yang membentuk alat dan praktik media baru (Suryanto, 2015: 606).

Mengutip Suryanto (2015) domain media komunikasi merupakan sarana untuk mengali dan membandingkan kualitas yang ada dalam tiap-tiap cabang utama sistem komunikas manusia. Roger Fidler mengelompokannya kedalam tiga domain, salah satunya adalah domain interpersonal yaitu termasuk bentuk komunikasi lisan/ekspresif satu lawan satu yang isinya tidak terstruktur atau dipengaruhi oleh pelantara eksternal. Selain itu, juga termasuk komunikasi antara menusia dan komputer yang bertindak sebagai pengganti manusia (Suryanto, 2015: 610-611).

Salah satu aspek yang muncul dari perkembangan media baru, dan semakin eksisnya ruang siber yang mempertemukan individu dan atau kelompok di area virtual dalam berkomunikasi yakni komunikasi yang termediasi komputer. Komputer, telepon genggam, atau perangkat terkoneksi lainya pada dasarnya tidak sekedar menjadi media yang memperantarai proses distribusi dan sirkulasi pesan, tetapi sebagai medium layaknya aspek serta lingkungan dalam komunikasi tatap muka. Hanya saja, komunikasi yang terjadi di media siber lebih banyak tergantung pada teks, baik teks dalam pengertian sesungguhnya maupun symbol, ikon, atau penanda lain yang mewakili maksud dari pesan (Nasrullah, 2014: 78-79).

Nasrullah (2014) mengutip uraian Mark Smith (1995) mengenai beberapa aspek dalam komunikasi di dunia siber yang dijelaskan sebagai berikut: Pertama, dijelaskan bahwa komunikasi atau interaksi di dunia siber tidak mensyaratkan keberadaan dan kesamaan antar pengguna (aspatial) media siber selagi fungsi interaksi melalui media siber itu masih ada. Bermakna bahwa interaksi tidak mesti terjadi pada waktu yang sama, sender dan receiver tidak mesti berada dalam lokasi yang sebagaimana yang terjadi dalam komunikasi dua arah, baik tatap muka maupun melalui media seperti telpon.

Kedua, menjelaskan bahwa dimedia siber interaksi bisa dikondisikan sesuai dengan, misalnya, jadwal yang diinginkan oleh pengguna saat tekoneksi ke dalam jaringan. Komunikasi bisa terjadi dalam kondisi ruang dan waktu yang sama (sesuai dengan, misalnya, jadwal yang diinginkan oleh pengguna saat tekoneksi ke dalam jaringan. Komunikasi bisa terjadi dalam kondisi ruang dan waktu yang sama (synchronous) dan bisa juga berbeda (asynchronous). 
Ketiga, bahwa interaksi yang terjadi dalam dunia siber pada kenyataannya terjadi melalui medium teks. Teks dalam bentuknya yang beragam dan juga melibatkan symbol (icons) menjadi medium yang digunakan oleh pengguna dalam berkomunikasi. Berbeda dengan komunikasi tatap muka dimana tanda-tanda seperti ekspresi wajah atau intonasi suara menjadi penentu dalam penyampaian dan penerimaan pesan, di dunia siber ekspresi dan intonasi diwakili oleh teks (the diatic expression).

Keempat, bahwa interaksi yang terjadi tidak mensyaratkan adanya kesamaan seperti status atau tingkat pengetahuan (astigmatic). Komunikasi teks di dunia siber tidak juga melibatkan visualisasi para pengguna sebagaimana di dunia nyata, yang terkadang dalam komunikasi tatp muka seseorang akan mengambil sikap tertentu ketika berhadapan dengan seseorang karena stigma yang muncul pertama kali dibenaknya. Status sosial, pangkat, jabatan, dan sebagainya yang membuat stratifikasi dalam kelas dimasyarakat nyata (offline) tidak berlaku di media siber. Satu-satunya "kelas" yang ada yaitu apa yang disebut dengan administrator, namun itupun hanya bersifat teknis dan pengatur lingkungan komunikasi yang secara teknis pula ditentukan (Nasrullah, 2014: 8081).

\section{Komunitas Virtual (Online Community)}

Berkembangnya media komunikasi
baru, terutama internet, telah
mentransformasikan pula bagaimana
interaksi diantara idividu sebagai entitas yang pada kenyataannya membawa fenomena sosial yang baru dan berbeda dari yang selama ini dipahami (Nasrullah, 2014). Internet menjadi tempat virtual dimana para indvidu bekerjasama dan berinteraksi sampai pada pelibatan terhadap emosi secara virtual (Rheingold, 1995).

Definisi komunitas virtual menurut Howard Rheingold (1993: 5) yang dikutip oleh Nasrullah (2014: 148) adalah sebagai berikut:

Virtual communities are social aggregations that emerge from the Net when enough people carry on those public discussion long enough, with sufficient human feeling, to form webs of personal relationship in cyberspace.

Nasrullah (2014) mengutip bahwa Rheingold (1995) menegaskan, bahwa system komunikasi di komputer pada dasarnya yaitu sekedar peragkat atau alat. Karena itu, komunitas yang muncul di dunia siber merupakan tahapan berikutnya dari penggunaan alat ini. Disadari ataupun tidak, penggunaan peangkat telah mentransformasi cara berkomunikasi dan dari landasan itu akan mepengaruhi pikiran serta jiwa individu didalamnya. Komunikasi di komputer tidak hanya dipandang sebagai pertukara data semata tetapi ada perlibatan individu di 
dalamnya...inilah yang membentuk koneksi antar manusia dan bukan hanya sekedar koneksi elektronik, koneksi antar manusia itulah yang bagi Rheingold akan membentuk komuntas virtual.

Selain mengambil bentuk di dunia siber dan dimediasi melalui perangkat teknologi, komunitas virtual dibentuk dari bertemunya para pengguna internet dalam waktu yang lama dan seiring dengan perjalanan waktu interaksi ini memunculkan semacam "rasa" diantara para pengguna tersebut. Inilah dua kat kunci dalam melihat komunitas virtual, yakni komunikasi dan rasa (feeling).

Pola jejaring (network) yang ada di media siber secara langsung maupun tidak akan menghubungkan para pengguna diberbagai tempat. Interaksi yang terjadi diantara pengguna ini pada akhirnya memungkinkan terbentuknya suatu jaringan atau komunitas siber (Nasrullah, 2014: 149). Terkait dengan komunitas siber, Tim Jordan (1999: 100) sebagaimana dikutip oleh Nasrullah (2014) mendefinisikan sebagai ruang siber tempat dimana sejumlah pengguna bertemu dalam ruang informasi yang sama. Bahwa pengguna tidak lagi beranggapan bahwa mereka sendiri di ruang siber, sebaliknya pengguna itu bisa membangun relasi dengan para pengguna lainnya. Komunitas siber, atau disebut Jordan sebagai virtual communiies, ini bisa beragam bentuk mulai dari forum diskusi di milis sampai pada permainan di MUD's yang merupakan bentuk relasi sosial didunia nyata yang muncul di dunia virtual. Reingold (2000: 5) menjelaskan komunitas siber sebagai agresasi sosial yang muncul di internet, dimana para penggunanya berinteraksi atau menggunakan ruang siber itu untuk berdiskusi dalam waktu yang lama serta adanya relasi yang terjadi diantara pengguna. Sementara Wood dan Smith (2005: 233) menjelaskan komunitas virtual sebagai lingkungan termediasi computer, tempat dimana para pengguna membagi kesepahaman mereka dan saling membangun relasi. Dari penjelasan tersebut dapat disimpulkan bahwa yang dimaksud komunitas virtual adalah komunitas yang terbentuk di dunia siber oleh para pengguna karena adanya kesamaan atau saling melakukan interaksi dan relasi yang difasilitasi oleh medium komputer terkoneksi internet (Nasrullah, 2014: 149-150).

Cantoni dan Tardini (2006: 161) dalam Nasrullah (2014) menyebutkan setidaknya ada beberapa syarat yang diperlukan untuk suatu komunitas virtual yaitu:

1. Lingkungan atau tempat untuk terjadinya komunikasi-interaksi;

2. Relasi diantara anggota terjadi dan dikelola secara elektronik atau online;

3. Rasa kepemilikan atau kedadaran anggota sebagai bagian dari komunitas tersebut; 
4. Struktur internal yang ada di komunitas; dan

5. Ruang simbolik yang saling berbagi yang diinterpretasikan dengan adanya aturan, nilai, norma, sampai pada ketertarikan.

Terkait teknologi di media siber pada dasarnya komunitas virtual bisa dibedakan menjadi dua jenis. Pembedaan ini dapat dilihat dari bagaimana transformasi komunitas itu terkait penggunaan ruang siber. Pertama, komunitas virtual yang terbentuk karena terjadinya komunikasi termediasi komputer. Para pengguna pada dasarnya saling bertemu dan berkomunikasi untuk pertama kalinya melalui media siber. Letak geografis atau perbedaan demografis menjadi cair, dan satu-satunya kesamaan yang ada diantara pengguna ini yaitu teknologi internet memfasilitasi pengguna untuk maksud yang sama. Kedua, komunitas virtual terbentuk dari penjelmaan komunitas di dunia nyata, dan komunitas ini menggunakan media siber untuk melanjutkan laju komunitasnya di dunia virtual. Artinya, komunitas model ini sudah terbentuk sebelum mereka bersentuhan dengan media siber. Sudah ada norma, nilai bahkan struktur yang dibuat di offline yang kemudian semua itu diwujudkan melalui komunikasi termediasi computer. Lechner dan Schimd (2000 dalam Cantoni dan Tardini, 2006: 160) mempertegas bahwa medium, sepeti media siber, memberikan pengaruh terhadap komunikasi yang terjadi di komunitas itu sendiri. Medium bisa memfasilitasi komunikasi dan di lain pihak komunitas bisa ditentukan dari adanya kesamaan medium yang digunakan oleh khalayak (Nasrullah, 2014: 151-152).

\section{METODE PENELITIAN}

Metode penelitian yang digunakan dalam penelitian ini merupakan metode penelitian Kualitatif. Dalam penelitian kualitatif instrumennya adalah orang atau human instrument yaitu peneliti itu sendiri. Metode penelitian kualitiatif adalah metode penelitian yang berlandaskan pada filsafat postpostivisme, digunakan untuk meneliti pada kondisi objek yang amaliah, (sebagai lawannya adalah eksperimen) dimana peneliti adalah sebagai instrumen kunci, teknik pengumpulan data dilakukan secara triangulasi (gabungan), analisis data bersifat induktif/kualitatif, dan hasil penelitian kualitatif lebih menekankan makna daripada generalisasi (Sugiyono, 2014: 8-9). Adapun objek dari penelitian ini adalah proses komunikasi interpersonal dan subjek penelitian dalam penelitian ini adalah anggota komunitas online rumahtaaruf.com. Informan dari penelitian ini terdiri dari dua informan yaitu informan kunci dan informan pendukung. Adapun informan-informan tersebuat merupakan anggota dari komunitas ta'aruf online yang sedang menjalani proses ta'aruf di rumahtaaruf.com sebagai informan 
utama dan juga pendiri dari rumahtaaruf.com sebagai informan pendukung. Pengumpulan data dilakukan dengan wawancara mendalam dengan keseluruhan informan. Adapun teknik analisis data yang digunakan dalam penelitian ini merupakan teknik analisis data model Miles dan Huberman. Bogan \& Biklen (Moleong: 2006: 248) dalam Satori dan Komariah (2014) mengemukakan bahwa analisis data kualitiatif adalah upaya yang dilakukan dengan jalan bekerja dengan data, mengorganisasikan data, memilah-milahnya menjadi satuan yang dapat dikelola, mensintetiskannya, mencari dan menemukan pola, menemukan apa yang penting danapa yang dipelajari, dan memutuskan apa yang dapat diceritakan kepada orang lain. Analisis kualitatif pada dasarnya mempergunakan pemikiran logis, analisis dengan logika, dengan induksi, deduksi, analogi dan komparasi (Amirin, 2000) dalam (Satori dan Komariah 2014: 200).

\section{HASIL DAN PEMBAHASAN}

Komunikasi meliputi proses encoding pesan yang akan dikirimkan, dan proses decoding terhadap pesan yang akan diterima, serta melakukan sintesis terhadap informasi dan makna. Komunikasi dapat terjadi pada semua level pengalaman manusia dan merupakan cara terbaik untuk memahami perilaku manusia dalam perubahan perilaku antara individu, komunitas, organisasi, dan pendapat umumnya (Suryanto, 2015: 53).
Dalam penelitian ini peneliti mengaitkan teori tersebut dengan proses komunikasi yang dilakukan oleh anggota komunitas rumah ta'aruf terutama pada pasangan yang terbentuk dari komunitas online rumah taaruf.

Komunikasi yang dilakukan oleh anggota komunitas rumah taaruf berdasarkan hasil observasi dan wawancara dilakukan melalui forum diskusi dimana seluruh anggota yang telah mendaftar dan memiliki akses berupa username dan password dapat bergabung dalam diskusi tersebut. Diskusi meliputi topik mengenai pernikahan dan problema anggota komunitas. Pada saat komunikasi dalam forum diskusi berlangsung, komunikasi interpersonal terjalin dengan baik antar anggta dan terlihat dari bahasa yang digunakan oleh semua anggota yang bergabung berkomunikasi dengan bahasan non formal namun tetap santun. Komunikasi antara anggota yang telah memiliki pasangan diawali dengan adanya proses pengiriman biodata oleh informan dan pasangannya sebagai anggota, bahasa yang digunakan dalam biodata merupakan bahasa formal dan membahas mengenai data pribadi anggota serta kegemaran, karakteristik pasangan hingga penghargaan dan keunggulan anggota dituliskan dalam biodata untuk menampilkan kejelasan pesan.

Selanjutnya proses komunikasi yang dijalani oleh oleh anggota yang telah 
memiliki pasangan selanjutnya adalah dengan tanya-jawab yang dilakukan melalui email sebagai media yang dipergunakan untuk menyampaikan pesan yang ingin disampaikan oleh anggota komunitas kepada pasangannya,topic yang dibahas. Melalui pertanyaan yang dikirim olehnya anggota komunitas juga dapat memahami karakteristik pasangannya dan menggali lebih dalam mengenai kehidupan anggota yang menjadi pasangannya. Komunikasi yang dilakukan meliputi pertanyaan seputar motivasi untuk menikah, bagaimana sifat dan sikap pasangannya, pekerjaan, status pernikahan sebelumnya dan hal-hal yang lebih mendetail mengenai keterangan diri pasagan yang sebelumnya telah dipaparkan dalam biodata pada tahap awal komunikasi.

Komunikasi selanjutnya dilakukan secara offline atau melalui tatap muka dengan pasangan, namun tetap didampingi oleh mediator. Komunikasi Interpersonal intim dilakukan pada saat pertemuan offline setelah anggota dan pasangannya sama-sama setuju untuk melakukan pertemuan secara langsung. Dalam proses komunikasi langsung anggota harus didampingi dengan mediator. Meskipun berkomunikasi langsung, berdasarkan pernyataan informan mereka tetap tidak boleh berkomunikasi terlalu lama dan tidak boleh bertatap muka dengan waktu yang lama. Untuk itu meskipun telah bertemu secara langsung pada tahap offline, ketiga informan tetap di damping oleh seorang mediator hal tersebut juga didukung oleh pernyataan kedua mediator yang mengatakan bahwa kedua belah pihak masih tetap didampingi mediator hingga adanya proses lamaran atau pertemuan kedua belah pihak keluarga, setelah itu barulah komunikasi diserahkan langsung pada kedua pasangan, jika belum ada proses pengkhitbahan atau pertemuan dengan kedua belah pihak keluarga, komunikasi harus tetap didampingi dengan keluarga. Dan pada saat pertemuan offline tersebut pembicaraan dilakukan oleh kedua belah pihak membahas tentang keseriusan pasangan dalam menjalani pernikahan, motivasi, visi-misi serta memverifikasi konsistensi jawaban pasangan yang sebelumnya telah ditanyakan pada tahap tanya jawab email.

Setelah adanya pertemuan secara langsung dengan pasangan sebagai kelanjutan tahap awal ta'aruf online dan tahap tanya jawab melalui email, komunikasi antara ketiga informan dengan pasangan tetap dilakukan dengan pantauan pihak kelarga dan komunikasi intens berdua antara anggota dan pasangan baru dilakukan saat adanya pengkhitbahan atau setelah adanya pertemuan kedua belah pihak keluarga masing-masing pasangan. Proses komunikasi yang dilakukan keduanya dilakukan menggunakan sms, line atau media chat lainnya dan persoalan yang dibahas tidak lepas dari diskusi persiapan pernikahan dan 
pendalaman pemahaman tentang karakter masing-masing. Karena komunikasi dilakukan melalui media online, komunikasi yang dilakukan antar anggota juga tidak dilakukan secara terus-menerus dalam waktu yang sama melainkan menunggu hingga salah satu pihak menjawab pesan yang dikirimkan sehingga komunikasi yang dilakukan tidak intens dilakukan setiap saat . Karena hanya berbasis teks, ekspresi yang ditampilkan oleh pasangan tidak dapat dilihat secara langsung atau spontan untuk itu kemampuan memahami dan meringkas jawaban dari pasangan dapat membantu ketiga informan untuk memahami karakteristik pasangan sehingga meyakinkan informan untuk melanjutkan komunikasi ketahap selanjutnya hingga tahap pernikahan.

Dalam hal memahami karakteristik pasanganya masing-masing anggota memiliki cara yang hampir sama yakni memahami karakteristik pasangan dari keterampilan masing-masing anggota untuk bertanya, menggambarkan informan melalui infomasi yang didapat dan keterampilan dalam meringkas jawaban yang telah didapatnya dari masing-masing pasangan. Informan pertama merasa bahwa ia dapat memahami dan mengamati karakteristik anggota lainnya dengan cara melihat informasi-informasi yang tertera pada biodata dan cara akhwat dekat dengan keluarga pada saat pertemuan antar keluarga.
Selanjutnya cara informan pertama sebagai anggota komunitas memahami karakteristik pasanganya adalah menggunakan feeling dan pendalaman karakter pada saat bertemu langsung. Untuk memahami karakteristik pasangannya para anggta juga melakukan pemahaman dengan kemampuannya untuk bertanya mengenai hal-hal yang bersifat kekeluargaan seperti bagaimana pasangannya berhubungan dengan orang tua maupun adik atau kakaknya hingga ia dapat mengambil point utama dari kepribadian anggota lainnya. Anggota memahami karakter yang ada dari kejujuran dan keseriusan pasangan dengan jawaban serta cara ia bersikap dan cara ia mengatasi masalah dan kemaharan yang ada dalam dirinya. Sedangkan untuk memahami karakter pasangannya melalui apa yang tertera dalam biodata dan melalui jawabanjawaban saat sesi Tanya-jawab setelah itu anggota memahami karakter pasangannya lebih mendalam melalui verifikasi atas jawaban yang telah pasangannya berikan.

Selama proses komunikasi yang dijalani oleh ketiga informan efek yang ditimbulkan adalah adanya pengetahuan tentang proses komunikasi dan ta'aruf yang benar menurut pandangan mereka, serta adanya hubungan yang baik antara kedua belah pihak hingga ketahap pengkhitbahan bahkan hingga ke proses persiapan pernikahan. Feedback yang ada juga digambarkan dengan respon yang baik dari 
semua pihak, mulai dari respon yang diberikan oleh informan kepada pasangan, respon baik yang diberikan pasangan kepada informan serta respon kedua belah pihak keluarga yang menerima masing-masing pasangan dengan baik dari adanya komunikasi yang dilakukan intens setelah pertemuan keluarga dan memunculkan hubungan yang baik dan komunikasi yang lancar. Feedback yang ditimbulkan juga digambarkan dengan adanya kesepakatan untuk melanjutkan setiap tahap hingga ke jenjang yang lebih serius.

\section{SIMPULAN}

Berdasarkan hasil obserbasi dan wawancara serta pembahasan maka dapat disimpulkan komunikasi antar anggota komunitas rumah taaruf dilakukan melalui forum diskusi yang disediakan oleh komunitas rumah taaruf pada websitenya www.rumahtaaruf.com. Proses komunikasi interpersonal terjalin pada saat anggota komunitas online www.rumahtaaruf.com menjalani proses ta'aruf offline. Dimana pada saat tersebut para anggota dapat bertemu langsung dan berkomunikasi langsung dengan anggota rumahtaaruf.com yang menjadi pasangannya, ekspresi digambarkan melalui raut wajah informan ataupun pasangannya yang sama-sama anggota komunitas rumah taaruf saat bertemu untuk pertama kalinya. Pada saat awal komunikasi terjadi, komunikasi lebih banyak dilakukan oleh pihak laki-laki daripada perempuan.

Komunikasi Interpersonal antar kedua pihak dilakukan dengan didampingi oleh orang tua atau kerabat pada untuk menjaga komunikasi yang dilakukan agar sesuai dengan ketentuan dan untuk menjaga kenyamanan antar anggota. Komunikasi dilakukan dengan membahas mengenai validasi jawaban yang sebelumnya telah didapatkan ketika tahap mediasi yaitu tahap tanya jawab melalui email dengan dipelantarai oleh mediator. Dan komunikasi interpersonal intens dilakukan apabila telah terjadi proses lamaran atau khitbah, komunikasi semakin sering dilakukan oleh informan dan pasangannya pesan yang disampaikan tidak luput dari bahasan mengenai persoalan persiapan pernikahan. Komunikasi ketiga informan selanjutnya di lakukan dengan menggunakan media sosial, seperti melalui pesan singkat, line, bbm atau whatsapp untuk mendukung komunikasi tatap muka yang mereka lakukan.

Melalui adanya komunikasi interpersonal antar anggota, hubungan yang baik dapat terjalin dan tergambarkan dengan adanya komunikasi dengan bahasa yang akrab antara anggota dan menciptakan hubungan kekeluargaan yang sesuai dengan tujuan dari masing-masing anggota. 


\section{DAFTAR PUSTAKA}

Hamid, Sanusi. (2014). Manajemen Sumber Daya Manusia Lanjutan. Yogyakarta: Deepublish.

Nasrullah, Rulli. (2014). Teori riset dan Media Siber (Cybermedia). Jakarta: Kencana.

Novianti, Evi. (2014). POLA KOMUNIKASI PASANGAN ANTARETNIK SUNDAMINANG DI BANDUNG (Studi etnografi komunikasi pasangan pedagang SundaMinang perantauan dalam pembentukan etnik di Pasar Baru Trade Center). Diakses dalam http://jurnal.unpad.ac.id/jkk/article/vie w/7383/3386

Robbins Stephen P, Timothy A. Judge. (2008). Perilaku Organisasi. Jakarta: Salemba Empat.

Satori, Djam'an dan Komariah, Aan. (2014). METODOLOGI PENELITIAN KUALITATIF. Bandung: Alfabeta.

Sugiyono. (2014). Metode Penelitian Kuantitatif, Kualitatif, dan $R \& D$. Bandung: Alfabeta

Suryanto. (2015). PENGANTAR ILMU KOMUNIKASI. Bandung: CV Pustaka Setia. 